\title{
PUBLIC TORT LIABILITY ADMINISTRATION: ORGANIZATION, METHODS, AND EXPENSE
}

\author{
Leon Thomas David* and Patterson H. French $\dagger$
}

In any unit of government where tort claims arise in some volume, there arise important problems of administration as well as legal and judicial questions. The law may require claims to be filed within certain time limits and with certain accompanying information; the forms and procedures by which this part of the process is handled may affect many later stages. The effectiveness of investigation is another factor that can affect the amount of equity and economy in the entire procedure. And since, in public tort litigation as well as in private, many claims are disposed of before actually reaching court, the system that is set up for rejecting or settling claims can play a large part in determining whether the proper claimants are paid and whether the amounts of payments are appropriate.

The survey by the Committee on Public Administration of the Social Science Council does much to throw light on present administrative methods and possible ways of improvement. Covering such diverse communities as Los Angeles, Chicago, Boston, Medford, and Austin, and supplemented by the study of Virginia cities by the Bureau of Public Administration of the University of Virginia, ${ }^{1}$ the survey directs attention usefully to the practical, day-to-day problems of administration that confront municipalities in their tort cases. Since these studies represent almost the only research from the administrative point of view, the present article will be directed primarily at problems that arise in municipalities.

\section{Administrative Machinery}

The law office of the municipality is almost necessarily the administrative center for the handling of tort claims. Unlike matters sounding in contract, where con-

* A.B., 1924, J.D., 1926, Leland Stanford Jr. University; M.S. in Pub. Adm'n, 1935, University of Southern California. Member of the California Bar. Lieutenant Colonel, United States Army, now Assistant Commandant, School for Special Service, Fort George G. Meade, Md. Assistant Professor and Director of the Legal Aid Clinic, School of Law, 1931-1934, lecturer, Schools of Law and Government, r934-I941, University of Southern California; Assistant City Attorney in charge of Torts Claims Division, Los Angeles, since I934 (now on leave); Deputy City Attorney, Palo Alto, California, 1927-1931; President, City Attorneys' Section, League of California Municipalities, 1930, director of League, 1931-1932, member of legislative committee, 1927-1930. Author, "Municipal Liability for Tortious Acts and Omissions" (1936); co-author of a study of the administration of municipal tort liability claims in Los Angeles published by the Committee on Public Administration, Social Science Research Council, 1939. Contributor of articles on public tort liability to legal periodicals.

† B.A., I928, Pomona College; LL.B., r93x, Harvard University; Ph.D., 1933, Columbia University. Member of the staff of the Office of Price Administration. Assistant Professor of Government, Yale University, 1937-1940; Ass't Sec'y, Committee on Public Adm'n, Social Science Research Council, r940-r942.

${ }^{1}$ For a further description of the survey, see French, Research in Public Tort Liability, supra p. 234. 
trollers and auditors may take the final role of arbiters, the tort claim is passed on to the law officer because of its indefiniteness, expecially in personal injury cases. This indefiniteness arises because of the unliquidated character of the claim, and because tort liabilities are developed by case law rather than by statute law. The law officer weighs the probabilities of liability or non-liability and advises the disbursing authorities accordingly.

Potential recoveries may loom so great, particularly in small cities, that the legal adviser may reject all claims and refuse to advise any payment except after suit. Law officers of larger cities may adopt the same course for political or other considerations. The fact remains that the law officer is almost always the central figure in handling tort claims. He must weigh the probabilities of losing a court action, he must tentatively assess the actual damages and the probable verdict, he must consider the expense of litigation, he must weigh the need for establishing rules of action through court decisions, he must consider the effect of settlement on other pending claims, and in the end he must form an estimate of the situation on which action can be taken.

It would be valuable to have a series of studies of the organization of the legal staffs of cities of different sizes, to show what methods they have developed for handling their tort work. The surveys that have been made show, as might be expected, that the larger cities, unlike the smaller, carry specialization of their tort work rather far. Thus, the Los Angeles study says in its introductory summary: "The organization of liability sections in the City Attorney's office permitting specialization in liability matters is a distinct advantage to the City." Claims are handled by three branches of the law department: the tort liability section, the automobile liability section, and the litigation division. The law department in Chicago was reorganized in I935 into four line and three staff divisions, with an assistant corporation counsel at the head of each line division, and with about a hundred lawyers in the line divisions. The torts division is one of the line divisions, with an assistant corporation counsel and about thirty lawyers. There is also an investigation division under a director of investigation. In Boston, tort litigation requires the equivalent of about five full-time attorneys, and there is also an investigation division with a regular photographer, a full-time physician and thirteen part-time "contract" physicians. The Austin law department consists of three full-time attorneys, and the city attorney estimates that about five per cent of his time is devoted to handling tort claims.

Organization for tort litigation will depend so much on the size of the work and the nature of the personnel that generalizations are difficult. It seems desirable to focus the work as far as is conveniently possible, so that certain attorneys and investigators can become especially familiar with the problems of this field. All of the studies show the advantage of effective investigation and the disadvantage of regarding tort claims as merely legal matters with the emphasis on actual litigation. Good administrative control is important; the Austin report mentions difficulties, since cor- 
rected, where two attorneys found themselves working on the same claim without proper clearance.

\section{Filing the Claim}

Adequate administration requires that the city know immediately when accidents or injuries occur. The injured party, with full knowledge of the mishap, can take steps at once to gather the names of witnesses, prepare a record of his injuries, take pictures of the scene of the injury, and generally prepare to make a good case. Unless there is some provision for notice, the city may know nothing of the accident until the claimant turns up with his file of evidence. The "blind case" presents all kinds of difficulties to the law department: witnesses are hard to find, the defect may have been repaired, and information about the injured party's condition may be meager.

Accordingly, legislatures of many states have passed statutes requiring that claims be filed within limited periods. Boston, Medford, and Austin, for instance, require the filing of a notice within thirty days, the first two cities by state law and the last by charter. The time in Los Angeles is ninety days and in Chicago it is six months, both required by statute. The authors of the Chicago survey felt that six months is too long, and the city has made two unsuccessful attempts in the legislature to get this changed to three months. The thirty-day provision seems to have operated without difficulty in the cities studied, and there is good reason to suggest that it be adopted more widely. Exceptions might be made, as in Boston, for instances of disability lasting more than the specified period.

There seems to be but one practicable method of forcing claims to be filed within the period set. This is to deny the right to sue unless claims have first been presented and rejected. Statutes making mandatory the prompt filing of claims are also useful not only in aiding the discovery of pertinent facts but also in determining potential financial liability, in facilitating prompt repair of the defect, and in preventing the disappearance of evidence of a kind that might not be specified in the claim itself. Timely notice allows timely investigation of the collateral circumstances. Here again there must be some mandatory feature to compel adequate disclosure. An oath may be required, "specification" may be demanded so that some degree of detail will be presented, or the necessary elements may be called for one by one. It would seem that any administrative procedure for the settlement of claims should embrace an adequate statute of this kind.

The statutes and the courts have almost invariably been strict in requiring observance of the notice procedure. The Chicago study poses an interesting problem arising out of such strictness. Suppose the claimant files a defective notice; should the city inform him of the need for amendment or, after the close of the period for filing, ask that the case be thrown out? Information is not given as to the Chicago practice, but reliance on a technicality in such a situation seems hard for any city to justify.

Absolute strictness may not be essential in matters of notice. A doctrine of substantial compliance will not necessarily create a situation that will get out of hand from the city's point of view. The city would be in little danger of being imposed 
upon if it had the right to waive notice requirements or allow filing of claims nunc pro tunc. As two of the studies point out, claimants are often ignorant of their rights against the city and of the proper procedure to enforce them, and it is important to protect legitimate claimants as well as the city. On the other hand, there is risk of favoritism and political manipulation. If waivers are permitted, the questions of who may waive, what is waived, and when waivers may occur are possible sources of difficulty.

Up to the time of filing suit against the city, the law officers in Los Angeles do not regard the claimant as one who is engaging in warfare with the city. Reasonable efforts are made to see that a claimant has accurate information about the duties of city offices and officers in connection with claims procedure. Standard claim forms have been prepared, so that the information given by the complainant may be as complete as possible, to his advantage as well as that of the city.

\section{INVESTIGATION}

It seems obvious that prompt and full investigation by the municipality is vital to the protection of the rights of both sides. While this investigation usually centers in the law department, help from other sources is important. The work of the law department itself can be facilitated by the use of a number of techniques that have been developed by certain cities.

Most statutes do not provide that claims come directly to municipal law officers. In Los Angeles, claims are filed with the legislative body in compliance with state law, although charter provisions require that claims involving the operations of the Water and Power Department be filed directly with that body. Since the city clerk is the clerk of the city council, claims are actually filed in his office. A standing rule of the city council then directs him to forward all such claims to the city attorney for investigation and report. In Chicago, when claims are presented by petition to the council by aldermen, reference may be made by that body to the city attorney. In Austin, the city manager usually makes the references to the law department.

Investigation has two elements: the work that is done by the law department's own staff and the cooperation that can be obtained from other sources, particularly from other city departments. This source is of great importance because such departments may have special facilities for certain kinds of inquiry and may receive information that the law department might not be able to get independently. At the same time, cooperation by an operating department in investigating claims may aid better administration in that agency by leading to changes that will prevent future accidents.

In Los Angeles, the Street Maintenance Division and other engineering divisions maintain staff photographers who visit the scene of the injury as soon as possible after the accident, whether or not a claim has yet been filed. Any property damage is appraised by the appropriate city bureaus or occasionally by specially employed appraisers. The Police Department reports to the Law Department on every accident involving a city car or city property injured by private automobiles, and police records 
are useful in other accidents. The city engineer also provides maps and models to illustrate street, sidewalk, and diversion cases.

All departments in Chicago are instructed to report any accident involving damage to city property or personal injury of any kind. This is usually done by letter, although a form has been developed for accidents involving city property. The Police Department sends to the law department's Investigation Division a copy of each police report for the preceding day. The records of the Accident Prevention Bureau of the Police Department are useful in providing statements taken at the scene of the accident, as, well as pictures and diagrams. Police officers from the district of the accident can often relieve the Investigation Division of some of the investigatory work. All such assistance facilitates early investigation while information is still fresh.

The Boston study says, "The work of the investigation division is marked by the close cooperation with the police and other city departments." The official photographer for the law department may be called to the scene by the police when a claim against the city seems likely. An elaborate system of forms has been developed through which the evidence from city departments and other sources is systematized.

In Boston and Chicago, elaborate systems of forms for reports are utilized by interested departments in furnishing the attorney with information. The danger of such forms is that important evidence that does not fit the form may be overlooked or not reported. At least, the form stimulates the attention of the attorney who through the investigators may develop the details of the case.

In every case of any consequence in Austin, the city attorney requests the head of the department concerned to investigate the condition causing the injury. Contour maps have been made by the engineering department to show street and sidewalk defects, and the city photographer frequently makes photographs. The police depart. ment is often relied upon for information. Partly as a result of its activity, accidents involving city-owned vehicles are well reported. On the other hand, the Austin study says, "The City Manager's memoranda on this subject of reporting accidents should be elaborated and an accident report form which would provide the legal staff in advance with knowledge of the facts relating to potential claims should be provided for all departments."

The law departments of all the cities carry on investigations to supplement the material they get from other sources. Promptness is important; the Los Angeles study attributes the city's success largely to better preparation than is made by the claimants. The other studies point out that the law department may often have, before the claim is filed, information of a kind that might not be obtainable later.

Adequate photographs, diagrams, site maps and other graphic materials are important. Aerial photographs are sometimes taken in Los Angeles to show flood and drainage damage. Taking pictures of the scene is a routine matter in the Chicagc law department; one investigator, aided by two members of the Accident Prevention Bureau, spends most of his time on this. The Chicago study says that the courts 
allow the use of motion pictures and that these are sometimes useful in important cases. A technical high school in Chicago built a table for the reconstruction of scenes of accidents which has proved helpful in preparing cases, although not used in court. A diorama of the Chicago municipal airport, used in the first case involving this property, was useful in keeping the verdict down. Austin uses contour maps prepared by the engineering department and pictures taken by the city photographer.

Chicago and Boston both subscribe to the service of accident reporting agencies. The Mutual Information Bureau in Chicago, a non-profit corporation that the city helped to organize forty years ago, covers accidents within a radius of 200 miles of Chicago, and serves the city, the Chicago Surface Lines, railways, utilities, and insurance companies. Members report claims against them on a Bureau form and receive in return a report including all previous accidents involving the claimant, all previous accidents at the same place, and information about the claimant, his doctor, and his attorney. The service has often been useful in ferreting out fraudulent or habitual claimants, as is the index bureau in Boston operated by private insurance carriers. The city attorney of Los Angeles encourages staff contact with insurance adjusters, through whom occasional spurious claims or other improper practices are discovered.

The taking of depositions becomes an important investigatory procedure in which, in Chicago, one attorney specializes. The Los Angeles survey reveals that the California law is liberal in permitting depositions to be taken for either party, and the plaintiff often seeks to develop sources of information from the officers and employees of the city.

In California the physical examination of the injured party before and in connection with the trial is customary, with legal process available when arrangements cannot be effected between counsel for such examinations. The Chicago law department uses the experts in the Department of Health to educate its lawyers in medical lore and employs life-size anatomical charts in preparing and trying cases.

The tort liability studies point to one common conclusion. The early and thorough investigation of tort claims, with its attendant expense, still proves to be the best weapon in combating claims that go to the courts. Principles of tort liability are fairly well fixed as matters of law. The attorney handling such cases day after day acquires a routine proficiency. It is the facts which are constantly changing. Hence, in expanding a law department to take care of mounting claims, many officers would profit by expanding the investigational, rather than legal, staffs.

Unfortunately, investigators sometimes employed by cities have little more than political activity to recommend them. Even investigation for criminal prosecutions requires no more schooling nor better techniques than the follow-up on tort claims. The investigator should be thoroughly trained in the elements of legal liability and evidence, and should have ingenuity and perseverance. He should be as skilled in his techniques as the lawyer is in his. The skilled investigator should have mastered the art of conversational cross-examination, that type of interrogation which avoids the crude direct approach and elicits the real data by indirection. Some good news- 
papermen have mastered this technique and may give helpful instruction. Junior lawyers may well serve apprenticeships as investigators.

\section{Disposal of Clatms before Litigation}

The number of accidents involving a city is always much larger than the number of suits that actually go to court. Some injured parties will never present claims. When claims are rejected after presentation, many claimants will fail to sue. If the city follows the practice of settlement in certain instances, many parties will accept the offered compromise. A similar weeding-out process occurs in private tort litigation.

This sifting process is mentioned because it occurs at the administrative stage of the claims procedure and involves many of the administrative considerations mentioned elsewhere in this article. Its effectiveness varies, but it can go very far. In Los Angeles, $82 \%$ of the claims filed during the period studied ended at the point of settlement or rejection by the city. Boston and Medford let more cases go to litigation, but $38 \%$ and $40 \%$, respectively, of their cases were disposed of before trial.

Claims Disposed of before Litigation.

\begin{tabular}{|c|c|c|c|c|}
\hline & Los Angeles & Austin & Medford & Boston \\
\hline Claims included & $r, 45^{8}$ & 139 & $3^{87}$ & 5,709 \\
\hline Settled before suit & 320 & 55 & 70 & 366 \\
\hline Rejected and not pressed. & 868 & 57 & 86 & $1,33^{*}$ \\
\hline
\end{tabular}

* 499 other cases listed as "pending or barred by statute of limitations."

The city council of Los Angeles formerly settled very few claims and then only where the law and the facts were clearly against the city or where settlement cost less than the cost of preparing and trying the case in court. Where contributory negligence was a possible defense, the issues of fact were almost always held to indicate the undesirability of settlement. It has been found in recent years, however, that settlement, after careful investigation and thorough consideration of legal factors, is actually a money-saver in many instances where the issues are evenly drawn. Time and expense could be saved if minor claims, perhaps under $\$ 50$ or $\$ 100$, could be paid from a fund appropriated to the attorney for the purpose. A small sum paid today may avoid a large lawsuit tomorrow.

The law department and the city council in Boston have not favored settlement before court action, as the figures show. The city has often settled small claims where its liability was clear, but it has had a strict policy of refusing to settle cases for their nuisance value. Even where the city's negligence seems clear, it takes full advantage of any possible legal immunity. The theory is that any relaxation of strict legal rules could easily result in abuse. The result is that administrative settlement has been unattractive to claimants who have pressed for it only in small cases where it would not be worth while to go to court. Most of the settled cases were property damage actions, while court cases almost always involved personal injury.

The high proportion of settled claims in Austin seems to have come from a definite policy of liberality. The general guiding principle here, as in the other cities, 
was that claims should not be paid unless there was a clear legal obligation. The council and the city manager seem, however, to have been willing to stretch the city's liability rather far if payment seemed desirable. The claimant's financial position and the seriousness of his injuries were considered; claims have sometimes been paid because the city administration did not want to be considered heartless by public opinion. Small cases were often settled to avoid spending time on them. As a result, some claims have been paid that represented moral, rather than legal, obligations to the degree that they would probably have been held invalid if tested in court. For instance, the city used its legal immunity to reject claims in only six instances, though this defense was available in all 23 cases filed against departments performing governmental functions.

The work of the law department in settling or rejecting claims before suit is often crucial. The delay, expense, and uncertainty of legal action give many parties no practicable alternative to accepting the ruling of the law officers. This fact should be recognized and accepted and procedures developed to make certain that claims are fully investigated, parties given an opportunity to present their claims fully, and action taken promptly. Both sides will benefit. The city will avoid expensive controversy while fulfilling its public duty of making just payment to claimants with legal rights. The claimant will not see his fair return melt away before a mass of obstructions.

Chicago has evolved machinery for the compromise of pending litigation, after trying various policies over the years. At one time, the department forced as many suits as possible to trial, thus protecting the law officers but increasing the volume of litigated cases and judgments. In I937, after study, a Settlement Committee was set up, consisting of the head of the Torts Division and two assistant corporation counsel. This committee considers the settlement of claims, at the claimant's request, after the case has reached "trial call" and has been fully investigated. Conferences are held with the claimant's attorney and a recommendation is obtained from the trial attorney in charge of the case. When a settlement has been agreed upon, the committee makes its recommendation to the corporation counsel who also obtains an opinion from the Appeal and Review Division. If the settlement is finally approved by the corporation counsel, the claimant makes a prima facie case in court and obtains his judgment. Thus there is actually a judgment even though the process is basically one of conference and compromise.

The Chicago study admits that this procedure might be considered cumbersome but points out that it protects the claimants and the city, and provides adequate records. The use of the procedure is increasing, and it helps to keep the city abreast of its tort work. The report later recommends that the Settlement Committee extend its activity to a large number of minor claims that now go unsatisfied because the law department lacks enough facts to recommend payment to the council. The Settlement Committee could hear the parties and prepare a report that would have at least advisory weight when the case came before the council. 


\section{ThE TIME FActor}

The length of time between an injury and the final disposition of a tort claim is of interest to both parties. The claimant is almost always interested in getting payment soon enough to relieve the financial burden caused by his injury. The city benefits if it receives notice of the mishap promptly so that it can conduct an effective investigation. Yet, a city that wants to keep payments small regardless of the validity of claims may not seek to push cases to prompt decision. Delay may make it more difficult for the claimant to sustain his burden of proof or discourage him sufficiently to cause him to drop the action. The city is, indeed, in a position of internal conflict. As one of the adversaries it is inclined to take all possible means of preventing or reducing payment, while as an agency dedicated to the public welfare it has some responsibility for seeing that claimants are not unreasonably burdened.

Promptness in disposing of cases is a test of efficiency both in the administrative aspects of tort work and in the judicial process. A city's law officers cannot be held responsible if a case must wait in the courts two years for trial, as is the case in Chicago and Boston. Yet in such a situation the citizen must wait for a decision long after the immediate cost of the injury has to be met. And knowledge of delays elsewhere in the system can point the way to improvements that need not await the reform of the judicial process.

The length of time between the injury and the filing of a claim is within the control of the injured party, subject to any legal limit on the period that may elapse. Chicago reports ${ }^{2}$ the greatest delay here, largely because the law allows a period of six months for making claims, a rule that the city has tried unsuccessfully to correct. The time between filing and the city's first action-rejection or settlement-is at least partly a matter of administrative efficiency within the law department's control. Austin averages about a month for this step, and it would probably be difficult to shorten this period if each case is to be thoroughly investigated by a busy department. Los Angeles requires two months, but the report says that this time could be cut down if the law department were provided with more adequate assistance. The Boston study states that many cases were formerly allowed to lag almost indefinitely, possibly with the thought that the claimants would allow the Statute of Limitations to run against them. That city now follows a policy of giving a decision, usually of rejection, on all claims. Since Chicago has no method of settlement, its most rapid action is that of "judgment by agreement" which takes more than a year.

The length of time between the filing of suit and judgment depends on the condition of the local courts. The Boston study says about conditions there, "For the cases filed during $1937-1938$ the plaintiff in the superior court will have received his money after an average time of about two years from the date of the accident; the corresponding time in the municipal court will have been nine or ten months." The Chicago study makes the general statement that parties must allow about two years

\footnotetext{
${ }^{3}$ For tables derived from the various studies showing the times elapsing between the successive steps in prosecuting claims, see David, supra. ED.
} 
for a decision in the cases that go through the regular process. In Los Angeles, Austin, and Medford, legal action can be finished in less than a year.

The length of time elapsing between judgment and final payment seems a particularly pressing problem in Chicago where judgments are paid about four years after rendition: Such a delay seems entirely indefensible; there is no reason why a city should be allowed to procrastinate in paying ordinary claims after liability has been judicially determined. Perhaps a loophole should be allowed where claims are so extraordinarily large as to threaten a city's financial stability; a provision for installment payments over, perhaps, a ten-year period would take care of such unusual situations.

\section{Amounts of Tort Claims}

In any given city and at any given moment, the cost of tort liability to the city is highly unpredictable. A citizen may stumble over a defective curbing and bruise his knee; a two dollar visit to his doctor may restore him to health. On the other hand, the construction of a sewer plant embankment in Austin resulted in claims of more than a hundred thousand dollars. Predictability in such a field can be achieved only by study of a large number of claims so that we can estimate the extent of a city's liability over a substantial period of time.

The present studies provide information in tabulated form on the amounts of claims at the various stages of litigation. They give an idea of the demands that have been made and the expense incurred in meeting them. The figures are presented in the original reports in yearly detail; they are summarized below:

\section{Amounts of Claims and Judgments}

Los Angeles Number

Claims filed

Rejected and not pressed

Settled before filing suit

Suit dismissed by claimant $\ldots \ldots \ldots \ldots \ldots \ldots$

Settled after filing suit $\ldots \ldots \ldots \ldots \ldots \ldots \ldots \ldots \ldots$

Judgments against city $\ldots \ldots \ldots \ldots \ldots \ldots \ldots \ldots$

Settlements after judgment $\ldots \ldots \ldots \ldots \ldots \ldots \ldots$

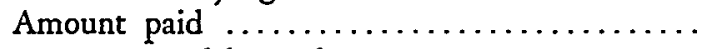

Amount saved by settlement.

Claims filed

Rejected and not pressed $\ldots \ldots \ldots \ldots \ldots \ldots \ldots$

Settled before fling suit $\ldots \ldots \ldots \ldots \ldots \ldots \ldots \ldots$

Suit dismissed by claimant $\ldots \ldots \ldots \ldots \ldots \ldots \ldots$.

Settled after filing suit $\ldots \ldots \ldots \ldots \ldots \ldots \ldots \ldots$

Judgments against city $\ldots \ldots \ldots \ldots \ldots \ldots \ldots \ldots$

Settlements after judgment $\ldots \ldots \ldots \ldots \ldots \ldots \ldots$

Amount paid

Amount saved by settlement $\ldots \ldots \ldots \ldots \ldots \ldots$

Judgments for city

$r, 429$
868
320
22
40
26
7

Number

4 II

86

70

14

67

27

3

r9

\begin{tabular}{rr}
\multicolumn{1}{c}{ Total } & Average \\
$\$ 7,331,598$ & $\$ 5, \mathrm{II} 7$ \\
$4,019,150$ & 4,630 \\
30,313 & 95 \\
195,882 & 8,904 \\
31,468 & 787 \\
90,695 & 3,488 \\
& \\
75,875 & \\
14,820 & \\
& \\
Total & Average \\
$\$ 68 \mathrm{r}, 210$ & $\$ 1,657$ \\
139,221 & $1,6 \mathrm{rg}$ \\
11,005 & 157 \\
41,412 & 2,958 \\
22,994 & 343 \\
17,524 & 649 \\
4,500 & 1,500 \\
4,000 & \\
500 & \\
55,400 & 2,916
\end{tabular}


Austin

Claims filed

$\begin{array}{rrr}139 & \$ 587,074.34 & \$ 4,224 \\ 49 & 129,836.06 & 2,649 \\ 53 & 6,788.81 & 128 \\ 8 & 105,098.00 & 13,137 \\ 6 & 3,742.53 & 624 \\ 4 & 2,672.30 & 668 \\ 1 & 1,600.00 & 1,600 \\ 2 & 26,500.00 & 13,250\end{array}$

Boston

Claims settled without court action

Total number of claims.

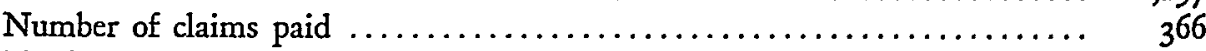

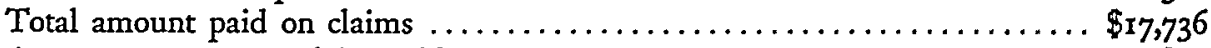

Average amount per claim paid $\ldots \ldots \ldots \ldots \ldots \ldots \ldots \ldots \ldots \ldots \ldots \ldots, \$ 48$

Claims paid after judgment

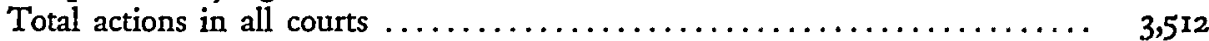

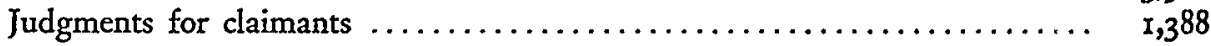

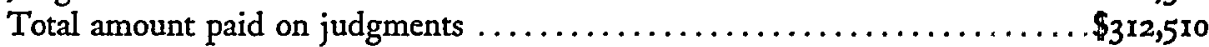

Average amount paid per judgment $\ldots \ldots \ldots \ldots \ldots \ldots \ldots \ldots \ldots \ldots \ldots \ldots$ \$225

In the three cities from which we have statistics, the size of claims varies greatly. The average in Medford is $\$ 1,657$ per claim, while in Los Angeles it is $\$ 5,117$. The amount is substantial in all three instances, however, and shows that a city's tort business, does not consist entirely of small claims for superficial street and sidewalk injuries. Of course, the average for a large number of small claims might be raised by a few large ones. It might have been useful to know the median for each city.

Another set of figures would have been valuable but could have been obtained only by a prohibitive amount of field work, if at all. This is the amount of damage or injury in those instances in which no claim was made. Four classes of individuals would be included here: people who are ignorant of their rights against the city, people whose claims are so small as not to seem worth the trouble of prosecution, people who feel that they would have difficulty in establishing the city's liability, and possible claimants who run foul of municipal immunity. If conditions were changed so that the first two groups were led to file claims, the number and total amount of claims would probably increase while the average amount per claimant would drop. If the law were relaxed to bring in the last two groups, the additional claims would probably be well varied as to size.

One should remember that the figures given for the size of claims, settlements, and judgments do not necessarily bear a close relationship to the actual cost of the injuries. The entries entitled "Claims filed," "Rejected and not pressed," "Suits dismissed by claimant," and "Judgments for city" give the amounts as they appeared in the claims or the pleadings. Parties often, if not always, ask for more than they expect to get. They may want to be in a good position to compromise. They may increase the amount of the ad damnum to get into a court with jurisdiction over 
larger cases. They may hope to sway the sympathies of a jury. They may take a chance on the inability of the defense to refute their claims. The Austin study mentions one instance in 1934 when a claim was raised from $\$ 2,062$ at the time of filing to $\$ 25,273$ at the time of suit. The Chicago study says that the formal ad damnum means nothing; it is usually $\$ 5,000, \$ 10,000$, or $\$ 25,000$ in the Circuit and Superior Courts and $\$ r, 000$ in Municipal Court. The Chicago records show that attorneys are often willing to settle for $\$ 200$ or $\$ 1,000$ where the amount claimed was $\$ 25,000$. The Chicago study says also that jury awards have little relation to the amounts originally claimed. The actual loss suffered, particularly in cases of personal injury, would be almost impossible to compute, even by the most elaborate claimant-to-claimant investigation.

In all three of the cities, the claims rejected and not pressed averaged less in amount than the whole body of claims. The most plausible explanation is that many of the smaller claimants felt disinclined to invest the time and money necessary to start legal action. Many of these claims may have been made as feelers to see if the city might happen to consider them favorably, when the parties knew that their legal position was shaky. A factor tending to keep the average amounts under this heading from going still lower might be the tendency of some cities to dispose of small claims by settlement rather than to bother about them further.

It appears strikingly from the preceding table that settlement before filing suit is usually available only to parties with minor losses. The average amount paid by this process was less than a tenth of the average amount claimed. This seems to bear out the statements made in the reports that cities tend to settle cases involving such small amounts that the expense of further fighting would be disproportionately high. It may also reflect the difficulty, from the claimant's point of view, of engaging in further litigation. (It might be interesting to have additional information on the number of larger claims that are settled for fractions of their face amounts.) There is little in the reports to indicate whether parties usually settle for less than their actual damages, but such a great disparity between claims and settlements would raise some question about the effectiveness of the procedure of handling tort claims.

Other evidence along the same line is presented in the figures from Los Angeles, Austin, and Medford, which show that claims settled after the filing of suits result in two to eight times as large payments as actions settled earlier. It is probably natural that the larger cases will be carried at least a step farther by both sides; moreover, any given case will be treated with somewhat more respect by a city's law officers if they know that the plaintiff means business. Further study of the records to compare the amounts claimed and the settlements made would throw useful light on the point.

An interesting question is raised by the entry, "Suit dismissed by claimant," in the preceding table. The average amounts in these suits are high, running in Austin to three times the average for all claims. The reason probably is that parties with substantial damages but with questionable grounds for recovery begin cases hoping to force settlements or to improve their legal positions as litigation proceeds, a sup- 
position given some basis by statements in the studies. Often the plaintiff realizes that the city is legally immune, that negligence cannot be established, or that the city can prove contributory negligence. The figures may provide some evidence for a belief that an extension of liability to exempted city operations might be relatively expensive for the city. Such a conclusion can be no more than tentative, however, because the figures do not give detailed information about the reasons why the cases were dropped.

\section{Cost of Administration}

Any governmental unit that assumes responsibility for the tortious acts of its employees finds that it has assumed two kinds of expense. The larger burden is that of paying claims. The smaller is that of receiving claims, investigating them, and defending the resulting legal actions. It is extremely important to have reliable information on the cost of handling tort business, as a basis for developing standards as to the proportion of a city's funds that can justifiably be spent in this kind of work.

A comparison of the amount paid to claimants and that spent in tort administration might give the basis for certain conclusions. If the amounts are relatively equal, there can be a presumption that the city is more interested in fighting cases than in cooperating with its citizens in the prompt payment of just claims. If the amount spent for administration is very small, the city may be failing to provide adequate investigation and consideration for its tort business. If administrative costs seem moderate, the expense per claim may serve as the basis on which to estimate the possible increase in operating expense if the city's liability should be extended to new fields.

It is difficult, in the absence of elaborate cost accounting, to determine just what part of the expense of a city's law department should be attributed to handling tort claims. However, some estimates, made in the various studies, may be helpful. Thus, as to the work of handling tort claims in Los Angeles, divided between the litigation division, the tort liability section, and the automobile liability section, the study says, "It is estimated that during the period covered the City of Los Angeles expended about $\$ 25,000$ a year in handling tort claims." The only figures given are for the automobile liability division, as follows:

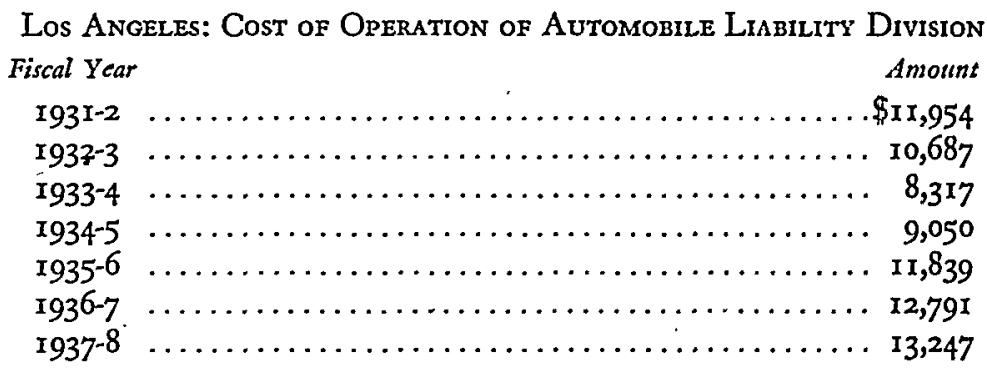

The Los Angeles study compares the amounts of claims referred to the automobile liability division and the cost of operating that division from July $x, 1933$ to Novem- 
ber I5, I936. Seven hundred claims, totalling $\$ 1,276,360$, were referred, and the totai expended in their payment was $\$ 89,596$. The directly charged administrative expenses were $\$ 29,206$. Thus the cost of operating the division was a third as much as all claimants received but only about two per cent of all amounts claimed.

The Chicago study does not give a yearly breakdown on the cost of tort litigation. Salaries in the Torts Division at the time of the report were $\$ I I I, 300$ for an assistant corporation counsel and thirty lawyers, with salaries from $\$ 2,000$ to $\$ 7,000$ a year. Six stenographers and four clerks received an aggregate of $\$ 10,000$ a year. Other expenses, not reported, include such items as supplies, membership in the Mutual Information Bureau, and compensation for experts.

The Boston report says, "Although it is impossible to arrive at an exact annual amount, it is probable that the cost of tort litigation to the law department of Boston is approximately $\$ 80,000$ to $\$ 85,000$ each year." About five attorneys in the law department give full time to tort litigation. The division of investigation employs a regular photographer, a full-time physician, and thirteen physicians who work part time on contract. The number of investigators is not given. In 1938 the division spent $\$ 4$, I0o for photographic services, about $\$ 20,000$ for medical services, and about $\$ 25,000$ for other activities. Witness fees, service of process, and the salaries of attorneys cost about $\$ 26,500$ in the same year. The rest of the expense went for items that could not be allocated accurately to the work on tort claims and includes such things as office supplies, general clerical help, and part of the salaries of higher administrative officials. A rough comparison with the average amounts paid out yearly for settlements, judgments, and reimbursement to employees for judgments against them indicates that the cost of administering tort liability has been approximately as much as the city pays to claimants. This amount is, of course, much lower than the amounts originally claimed.

The Austin study says, "Considering the amount of claims the costs of the administration of tort liability have been kept at a low level." The cost of administering the legal department is as follows:

Austin Legal Department: Cost of Operation

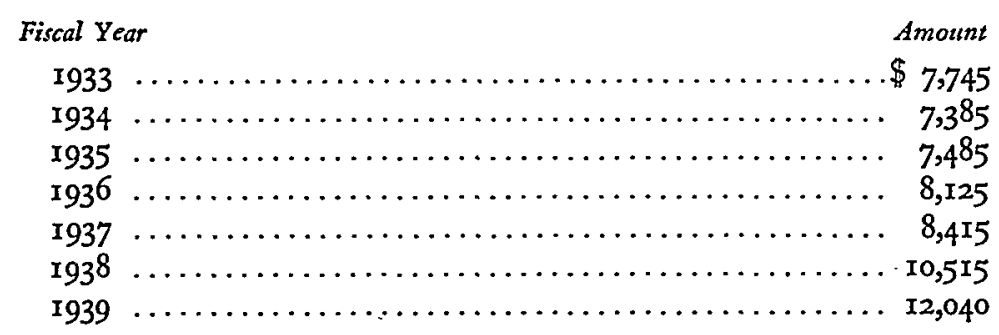

All except $\$ 200$ to $\$ 500$ of this amount was allocated to the payment of wages and salaries. The proportion of the total attributable to tort business was not estimated, but the city attorney thought that about five per cent of his time was spent in this kind of work. There were occasional special expenses, such as the hiring of extra 
attorneys in a large case at the cost of $\$ 600$ and a fee of $\$$ roo paid to an engineer for expert testimony in the same case.

Organization of municipal agencies to deal with tort claims becomes more definite as the city reaches a population of roo,000 and upwards. As has been noted, the modern tendency is to turn over the details of administering of tort claims to the city attorney or the corporation counsel, rather than to such fiscal officers. In the larger cities, specialization of this sort, with modern techniques of investigation, preparation, and presentation, has proved to be the best defense of the city against spurious claims and adverse judgments. Likewise, the litigant or claimant may profit by the expedition of an adequate administrative organization. Whether he does, depends in part upon the local governmental attitude. $U_{p}$ to the point of actual litigation, it would seem desirable to aid the claimant in purely technical matters, such as filing claims in proper form.

The smaller cities, with only occasional claims, cannot specialize in administrative procedures. Hence, it is desirable that attorneys be more familiar with the tort liability practice and that the generally antagonistic attitude toward the claimant be modified in the interest of justice. If and when administrative methods can be developed to relieve small cities from the blighting effects of occasional large judgments we can hope for more adequate relief to claimants.

The elements constituting good administrative practice, as developed by the cities surveyed, deserve careful consideration and development in any governmental agency dealing with tort claims. 